\title{
Utopian Impulses during the English Interregnum: John Eliot and Gerrard Winstanley
}

\author{
Alice Manuela Martins Guimaraes *
}

\begin{abstract}
During the English Interregnum John Eliot and Gerrard Winstanley wrote their utopias in different hemispheres, depicting different patterns of utopias which offered alternative models of code laws for a divine platform of Government they urged the English to emulate. Within this extraordinary historical and political context, political action and utopian literature enjoyed an unparalleled symbiosis. Through a close analysis of the parallels and main differences of their works we can get deeper insight the thought and culture of that period. Their utopias, The Law of Freedom and The Christian Commonwealth, share the same political agenda towards reality and convey a similar plan of realization in their political aspirations, but each author displays a uniquely different emphasis and approach to utopia, differing from one another in epistemology, ideology and social and political emphasis. However by assessing the potential of these utopias we can trace some bridges linking their authors' perceptions to shape a better future for the same country. Their radicalism concerning the royalist power, their concern to eradicate the old civil and ecclesiastical system, the search of a political order and stability, the improvement of social conditions and religious tolerance, were depicted within their utopian texts. A close analysis of these texts which have never been grouped and brought together by scholars, illustrates the range of the political imagination of their authors and provides an opportunity to examine different ways to deal with political and social concerns and different perspectives for ideal solutions by such writers who were so committed to connecting utopia to reality.
\end{abstract}

Keywords: Utopia; Interregnum; Eliot; Winstanley

\footnotetext{
* Corresponding author: Alice Manuela Martins Guimaraes Assistant Professor, The Humanities Department, the Open University, Portugal, e-mail: aligui2@ hotmail.com
} 
The word Utopia first occurred in Sir Thomas More's Utopia, published in Latin, in 1516, as Libellus vere Aureus nec minus salutaris quam festivus de optimo reipublicae statu, deque nova insula Utopia "A truly golden handbook, no less beneficial than entertaining concerning the highest state of the republic and the new island Utopia"; but utopias are far older than their name. Plato's Republic was the model of many, from More to H. G. Wells. Although the term is a modern creation, which means that the concept itself of utopia was stranger to ancient Greeks; although, in his first usage, the term specifically refers to the politics and to a specific literary genre, the "literary utopia", utopian thought is identifiable in ancient Hellenistic literature and culture since its very beginning.

The modern utopia itself with its political implications, as first theorized by More, traces back to an ancient Greek tradition of searching perfection and the best constitutions whose first model was Plato's Republica. Since then and over the centuries patterns of uniformity and divergences have been displayed. The literal meaning of "Utopia" is not obvious. It is both the "good place" (eutopia) and "no place" (ou topia). This ambiguity has provided the basis for subsequent studies of utopias. To define the ambiguous concept of utopia, much has been proposed. In this paper, however, I will follow the definition advanced by Ruth Levitas in her work, The Concept of Utopia, where she takes almost whole book to discuss the reasons this definition surpasses others, whether those formulated descriptively, formally, or functionally:

\footnotetext{
Utopia expresses and explores what is desired; under certain conditions it also contains the hope that these desires may be met in reality, rather than merely in fantasy. The essential element in utopia is not hope, but desire - the desire for a better way of living. (191)
}

Her definition is particularly helpful for me, in looking at what strikes me as clearly utopian discourse in my chosen writers.

I take as my example John Eliot and Gerrard Winstanley intending to redeem the importance of their dynamic utopias which released utopism from its traditionally passive position within the realm of contemplative literature and transposed it into the active realm of 
Interregnum politics. The "desire for a better way of living and the hope that those desires may be met in reality" as advanced in Levitas' definition, became aspirations both in England and New England and could expand visions projected into what Keith Thomas called "actionoriented utopias" (24). It is in this context that I inscribe Eliot and Winstanley's utopias.

Actually, in the seventeenth century utopia reached a unique status. It had become a serious means of both expressing dissatisfaction with the status quo and of suggesting real improvements to it. Interregnum utopias were shaped by the expectations and violence of the English Revolution, so more than ever, utopia orientated itself to a hopeful and expectant reality, reshaping its former boundaries and reinventing itself as reality utopia. The genre undergoes a transformation and redefines itself in a new and more reality-oriented function (Thomas, 24 -43). Utopias in the Interregnum were no longer fictional or contemplative.

The English Interregnum - the period of English history between the second Civil War and the Restoration - opened up unlimited possibilities for shaping the country's future and witnessed a supreme surge of political imagination which would develop in utopian visions and writings. Much has been written on the period 1640-1660, concerning the utopia model, a time when a crisis in religious, political and social consensus coupled with the resultant breakdown of control of the presses and allowed the expression in print of startling and utopian views. The existence of a variety of utopian texts provides a good opportunity for getting deeper insight into the thought and culture of that period, since different authors addressed these issues differently. Despite the abundance of existing scholarship, the Interregnum continues to provide fertile ground for new research. In this context my chosen utopias exemplify the variety and diversity of expression available within the utopian writings of the Interregnum.

Although some utopian designs in this period were lofty abstractions, theoretical models of the ideal society and speculations on radical reform in all spheres of life, there were others, such as John Eliot and Gerrad Winstanley's, that depicted real, active, empirical models 
which seemed to be within the reach of possibility. By delving into these utopias we can find out some parallels and interactions between them, assess their potential and trace bridges which link their authors' perceptions to shape a better future for the same country.

The Christian Commonwealth and The Law of Freedom, respectively from John Eliot and Gerrard Winstanley, were written in the very same year (1652 although the former was only published in 1659) in different hemispheres and addressed to the same person - Oliver Cromwell, not yet Protector but Lord General and the most powerful person in the country. Apparently the two utopias have nothing to do with each other, except the occurrence of being written within the same timeframe and thus written within the same historic and political context - Puritanism and the English Interregnum. As the authors are bound by a shared culture and history, we can easily find evidence of some common concerns regarding the English society of the Interregnum, such as political order and stability, eradication of the old rules, improvement of social conditions and religion tolerance, which dominated the political conscience of their culture.

Sharing the same cultural and historical background inspires some similarities and often results in writers addressing some of the same themes in their utopias. However, while operating within the same culture, the individual manifestation of any utopian vision is still influenced by personal factors of its creator - his ideology, religion, environment and social status. In this respect utopias become a reflection of the author and the epitome of an author's interpretation of society or, as Eliav-Feldon puts it, "the embodiment, the crystallization of the entire Weltanschauung of the author" (11). While utopia always constitutes a search for a better reality, the specifics of this reality or even how this search should be conducted depend on the individual author. Although both Eliot and Winstanley tried to define the better society offering models of code laws and supporting their rhetorical speech by the Scripture, none of them gave the same solution for solving the legal, political, or religious problems that, according to them, lay at the root of social imperfection. 
Both authors share the same political agenda towards reality and convey a similar plan of realization in their political aspirations, but each of them displays a uniquely different emphasis and approach to utopia, differing from one another in epistemology, ideology and social and political emphasis. While Winstanley is primarily concerned with religious freedom and imagined an agrarian equality, Eliot stresses his attempt to build a theocratic commonwealth, the establishment of a scriptural civil policy where all man-made policies would be completely eradicated, particularly the religious ones, and would be replaced by their biblical counterparts.

Imbued by the same apocalyptic and millenarian expectations of the period, each of them, tried to reshape and regenerate the English commonwealth displaying different dimensions of heterodoxy concerning their teleological and political arguments. The search for a better future and the fulfilment of apocalyptic prophecies were, by then, impulses that flowed from Europe to New England and they were part of the apocalyptic design that dominates both the Puritan divines in New England and the Puritan revolutionaries in England. Therefore John Eliot, an English puritan missionary in New England and one of the most remarkable missionaries of all time, wrote his Christian Commonwealth, based upon his experiment with the Algonquian Indians while Gerrard Winstanley, the revolutionary leader of the Diggers' movement in England, in his utopia The Law of Freedom in a Platform: or, True Magistracy Restored, published in 1652 after the collapse of his experimental Digger community of shared farming on common lands, preached a revolutionary gospel of social reform, a Christian society established by the prohibition of private ownership of real property. He is also remarkable in his eagerness to overthrow and cast out the orthodoxies of theology, government of church and state, traditional English law, social hierarchy, and the entire economic system of monetary exchange and private property rather than merely modifying existing structures.

Winstanley's communities of Diggers at St. George's Hill and Eliot's Praying Town of Natick with the Algonquian Indians provided the empirical basis for their writing. In that period no other utopist remained 
so committed to connecting utopian writing and practice. So much as Eliot, who worked intensely to convert the proselytes and "obsessively charts the tansformations between utopian writing and practice" (Holstun, 103), proposing "a large-scale repetition of the Indian Praying Towns organization he had already determined experimentally to be possible" (Ibidem,150), Winstanley was a man of action: "Action is the life of all, and if thou dost not act, thou dost nothing" (315). And even in his writing he emphasizes action and challenges his reader to move beyond religious orthodoxy and the politics of self-preservation. His utopia is a call to action and pushes readers to act through questioning the status quo and reforming society through law. As Nigel Smith observes: "In developing an interpretation of the Bible as he did, he dug on the page, as well as in the ground. By reading him carefully, you the reader, dig too" (Smith, $58)$.

John Eliot tried to regenerate that part of the English population with no voice, no law and no discipline whom the New England puritans saw as displaced (the natives) and tried to integrate them into the newly enclosed and rationalized New England landscape. He saw in this group of real persons the raw material to embody his utopia. In the very same way, Winstanley saw the raw material to embody his utopia in the people of England who had no land and no voice (the landless people brought about by the enclosure of the lands) preventing them of becoming a cluster of unemployed, homelessness, heathen, vagrants. As James Holstun points out, the Puritans found displaced and dispossessed people of England and New England the raw material for their utopias:

The enclosure of New England proceeded that of England. The Indians possessed the lands by natural right... As the enclosure of English commons' ground often began with a single large landholder overstocking the commons, turning it into private property, so white expansion in New England often began with the Indians' allowing whites the use for settlement and cultivation of Indian commons grounds (...) The dispossessed and displaced English tenants and Algonquian tribesmen soon found out that enclosure is irreversible. Just as Winstanley and the Diggers responded to the displacement of rural tenants by encouraging them to enclose and cultivate common grounds such as those at St. George's Hill, so Eliot and his missionary 
colleagues worked tirelessly to acquire tracts of land for Indian

Praying Towns. (107-08)

In this context, Eliot's utopian commonwealth was situated within his own work among the Algonquians who, like the Israelites upon departing from Egypt, had no existing law and government. Wistanley, by his turn, envisioned a utopian Christian society as experienced with the Digger community, based on the passages in the Book of Acts in the New Testament (Acts 2:44-45) where the Early Christian community was described as classless, and holding all property in common. Therefore they both displayed their utopias with a double authority: their empirical basis and the Bible's authority.

In a revolutionary century that mingled political activity with religious profession thousands of people not only believed but also militated to transform the English Commonwealth in a sort of replica of the biblical Canaan, a simulacrum of God on earth. In this context, the writers of the English Interregnum advocated the need to create the necessary conditions prior to the second advent of Christ, which, they believed, would be in England. In order to prepare England, the "elected" nation, for this epiphany of redemption and glory, Eliot and Winstanley drew models of an organized type of government, established according to a divine plan, sanctioned by Scripture, under which "people composed their differences and came into a sweet harmony of obedience and subjection to Christ" ( Eliot, 136-7).

According to Holstun:

The Bible ... gave a previously unimagined relevance to social reorganization in such utopian communities and writings as Gerrard Winstanley's community of Diggers at George's Hill and his Law of Freedom and John Eliot's Indian Praying Towns and his Christian Commonwealth. These texts seem to offer themselves as patterns for social organization. (34-35)

All along Eliot's text, the quotations of the Bible aimed to support his proposals for the utopian division of persons and for the formation of popular government. He drew his civil model from the Hebrew theocracy of Exodus:18 and his ecclesiastical model from the Book of Revelation 
where the Hebrew theocracy returns in a Christian form. Likewise, Gerrard Winstanley in The Law of Freedom supported his rhetorical speech in the Bible turning to ancient Israel for his model. Key texts for Winstanley included Acts 4:32 or, as he paraphrases it: "And when the Son of man, was gone from the Apostles, his Spirit descended upon the Apostles and Brethren, as they were waiting at Jerusalem; and Rich men sold their possessions, and gave part to the Poor; and no man said, that ought that he possessed was his own, for they had all things common". He also drew form Genesis the argument that since all human beings are descendent from Adam and Eve, no one is better than another for any reason. In other words, what he depicted is a religious and political program under the new covenant that came with Christ.

Their works seem to offer themselves as patterns for social organization and templates for the English commonwealth as they were supported by their empirical base and authorized by the text of the Scriptures. We can deduce from Eliot and Winstanley's rhetoric a breviarium of biblical rules, a transliteration from the text of the Scriptures to the legislative text, which would shape and reorder the social and political English reality. The authors developed a pure political determinism offering alternative code laws for a divine platform of Government which they have tested with their previous experiments and which they urged the English to emulate.

John Eliot proposed a detailed scheme for a theocracy or "Holy commonwealth", a divine platform of government "taught by God himself" as he put it in his Christian Commonwealth. The author advocated the establishment of a scriptural civil polity in England, the creation of a congregational state church and the adoption of a biblically based code of laws. Eliot proposed to divide society into groups of tens, fifties, hundreds, and thousands and so forth, each of which should choose its rulers, who in turn should choose their representatives in the higher councils. He worked out this surprising scheme in great detail, going into relative fine points regarding at which level of the pyramid capital crimes should be tried, and so forth. He didn't provide any geographical map, as More, Bacon and Campanella did. Instead he provided a detailed administrative and legal structure. 
Accordingly, in the same spirit, Winstanley's Law of Freedom offered a complete and detailed code of laws for the immediate achievement of a communist state, a "Platform for the Government of the Earth without buying and selling". Throughout his utopia Winstanley presents theological justification for the set of laws he lists at the end. $\mathrm{He}$ generates a series of compelling arguments supporting the establishment of agrarian communism and the simplified legal structure he outlines. Unlike More and Bacon who represented and instigated social reform through the geographical organization of their utopian islands, Winstanley focuses on the law that will ensure common ownership of land and equal labor for every citizen.

A close analysis of Winstanley's ideas reveals the uniqueness of his belief that law had to create the preconditions for the emergence of his communist utopia. The replacement of the old legal system was a high priority for the author. In Winstanley's commonwealth, so much as in Eliot's, everyone should be aware of the law and be able to represent himself in a court law accordingly. He intended to keep the legal system as simple as possible as he believed "Short and pity laws are best to govern a commonwealth" (Winstanley, 377). The result of his legislative endeavor was a list of sixty-two rules and regulations to monitor all social interactions in the commonwealth. The laws in his community regulated not only the economic and political organization but the social behavior as well. They provided the punishment for all crimes, prescribed the obligation of agricultural work, the distribution of goods and food, the ban on trade and use of currency, the annual elections, officers functions, the family life, education, powers of the Parliament, etc. "There will be rules made for every action a man can do" (138). The consequences of breaking any of these sixty-two laws were severe.

The Law of Freedom and The Christian Commonwealth represented a commonwealth of law where their authors revealed a functional code of laws in order to define the boundaries of their utopias. For Eliot as for Winstanley popular government was the rule of written law and monarchy the rule of men alone. Thus they rely in such a code of strict laws. In their commonwealths Laws must be "few and short and often read (... ) as Moses's laws in Israel's commonwealth: the people did talk of them when 
they lay down and when they rose up, ... so that they were an understanding people in the laws wherein their peace did depend" (Winstanley, VI,378-9) . In Winstanley's political thought, law establishes the foundation of society and law provides the power structure that ensures the continuation of the society's values. "And if these be the days of resurrection to power, as we may hope, because the name of Commonwealth is risen and established in England by a Law, then we or our posterity shall see comfortable effects" (II, 311).

As the quotation illustrates, the establishment of an ideal Commonwealth through the reformation of law was inextricably linked to his millennial expectations of Christ's "resurrection to power". In the very same way Eliot's utopia displayed much evidence of the importance of the law for the people as well as for the whole commonwealth in defense of the truth and equity.

\footnotetext{
As for such wholesome, just, and wise Laws, as any Nation hath already made, the Wisdome of the Lord will teach his People to refer them ...demonstrating the truth and equity thereof, by the Word of God (....) And great shall be his Dominion: for the Stone Christ shall grow to be a mountain filling the whole earth: all men submitting to be ruled by the Word, in civil, as well as Church-affairs (Eliot, Preface, 22-24)
}

As we can deduce by Eliot's rhetoric, in his utopia, all man-made laws should be replaced by their biblical counterparts. Therefore, for both authors, law would have to be known by all people of community and for this reason laws should be very clear and simple. In their Utopias everyone should be a legal expert. This idea of a simple and plain legal system as advocated by Eliot and Winstanley was common in the utopian tradition. In Plato's Republic, the rulers are to be a group of intelligent, unselfish men called the guardians or philosopher-kings, who conduct public affairs for the good of the whole nation. In More's Utopia boasts a simple and self-contained legal system. Likewise in Campanella's City of the Sun, it is stated: "They have but few laws and these short and plain, and written upon a flat table..." (197).

The exceeding complexity of laws resulted, according to Winstanley, in the ignorance of people regarding the law and the 
dependence on lawyers. He states: "But now if the laws were few and short, often read, it would prevent those evils; and everyone knowing when they did well and when ill, would be cautions of their words and actions; this would escape the lawyers craft" (378). As much as Winstanley understood lawyers to be the primary enemies of his cause, so Eliot thought the slow course of justice in England, was due both to the complexity of English law and to the self-interest of the lawyers (Cogley, 39). So, in order to provide for a "speedy and easy determination" of judgment, Eliot established as many courts of law as the Word of God allowed, and he abolished the profession of the lawyers. No lawyer walked the pages of his Christian Commonwealth, where all cases were heard only between the rulers, the defendant, the plaintiff, and the witnesses (Cogley, 79) .

And to avoid the disrespect of social rules and the increase of human sin which was seen by Winstanley and Eliot alike "as human iniquity", they approved monitoring the human behavior through public surveillance. "Sin will grow apace, like ill weeds, if it be not always watched and often weeded out" (Eliot, 145). As in traditional utopias, the idea of public surveillance and scrutiny is accepted and encouraged as part of the ideal; it is a way to preserve the ideals of the utopian system. In Winstanley's utopia the presence of governmental monitors or overseers, is ubiquitous; in fact every citizen over the age of sixty becomes automatically an official overseer, ensuring that no citizen neglects his duties to the commonwealth. His tight web of surveillance was complemented by a sophisticated system of communications where the postmasters represented the idea of a national information service. The network of officials gathered information and sent reports about the affairs and happenings of each parish to a central point where the information was collected and redistributed to every parish. Such a network allowed the early detection of potential disasters or threats in the commonwealth, such as famines, invasions and insurrections. However, the gathered information was not collected and handled secretly; it was openly revealed to everyone. Therefore, the commonwealth became a transparent society - everyone was equally scrutinized and scrutinizing. This high degree of governmental scrutiny and control was an everyday 
life in his commonwealth except for religion that remained surprisingly liberal.

Likewise Eliot's advocated a similar monitored model for the government of his utopia by mutual surveillance. In his Christian Commonwealth every order must "cohabit together as near as may be, because that doth tend to facilitate both the watch and the word of Lord's government" (148-9). Everyone changing habitations must first obtain the permission of the rulers of the area he was moving to (Cogley, 78). Their utopias shared a high level of radicalism concerning the whole reorganization of social and political issues and individual regeneration as well. Eliot, was an antimonarchical radical who advocated the eradication of all human-made systems including the monarchy. His ideas about government were highly radical. He envisioned the ultimate destruction of monarchy and, in fact, of all governments other than an extended version of the system of rulers.

For him, monarchy was a human contrivance. "Monarchs were terror to men because they governed with their own interests and not those of God, in mind" (apud Cogley, 77). He expressed his high degree of radicalism requiring England to abandon the constitutional theory and deduce its forms of Government only from the Scriptures. His contempt for human creations led him to see the Millennium as the restoration of the primitive institutions in its original splendor. In The Christian Commonwealth he stated that God had determined that all the institutions created by man would disappear and would be replaced by their Biblical counterparts. His commitment to restore the old law of Israel reached such proportions that it seemingly entailed the total eradication of all human legal systems of England including the monarchy that he saw as a human invention. What he proposed was a radical reordering of civil government which would free England of the episcopate. In The Christian Commonwealth there was no room for monarchy or the Papacy, and both were, for Eliot, surely constructs of the devil:

It is prophesied, Daniel 2:34,35, etc. Thou sawest till that a stone was cut out, without hands, which smote the image upon his feet that were of iron and clay, the brass, the silver, and the gold, broken to pieces together, and became like the chaff of the summer threshing-floors; and wind carried them away, that no 
place was found for them: and the stone that smote the image, became a great mountain, and filled the whole earth, etc. which prophecie doth clearly foreshow the forenamed points; for there is a epitomy of all the Monarchies, Governments, and Polities of men, who have had their Humane Glory in this world: the last, and strongest of all Dominions is the Roman, so mixed and interwoven in many States, by the combining of that dirty Roman Religion, with civil Powers...(Eliot, 55)

He believed that the Old Testament government he wished to put in Natick and the other praying towns was ultimately the form of government that Christ desired for the nations of the world. His treatise proposed nothing less than a plan to put the Exodus system of incremental rulers in place of the governments of the world. For him, it was urgent to reorder radically the civil government as well as to rid England of episcopacy. His radical views about monarchy also helped him to interpret the rule of Massachusetts Sachems as a "tyranny" that needed to be thrown off if the work of Christ was in progress. The purpose of Eliot's utopia was to convince the revolutionary leaders to establish the millennial civil polity throughout England.

Likewise Winstanley wanted Cromwell "to play the part of a classic lawgiver and remake society in a new image, as Lycurgus was said to have entirely recast the constitution of Sparta" (Robert Appelbaum, 163), sanctioning his speech in the Bible. Winstanley informed also radical perspectives as he envisioned what Beranard Yack calls a "total revolution". "Winstanley was aiming to transform the whole of human character by attacking the fundamental sub-political roots of interaction" (Yack, 9). Appelbaum gives a clear explanation of Winstanley's radicalism when he writes:

If a number of his contemporaries wanted distributive justice, Winstanley wanted to put an end to distribution. If a number of his contemporaries wanted to make significant adjustments in the organization of resources and political rights, Winstanley wanted to transform the meaning of economic resources, and to restructure the relationship between the political individual and the socio-economic community. If a number of his contemporaries were anticipating a new age for the benefits of the saints, Winstanley was anticipating a new age for the benefit 
of all. And in this new age the "all" would itself be transformed.

(155)

Appelbaum emphasizes how truly radical Winstanley was - he didn't just want political change - he wanted to alter the human psyche and soul to eradicate the need to differentiate between "mine" and "thine". Winstanley wanted to renovate the interior of human beings not just their exterior circumstances, and he had hoped that the Digger movement would inspire spiritual reform and sharing of land and farm labor, which would initiate the rising of Christ in the hearts of all English people and start the millennial reign of righteous government. In the context of early English utopian thought, even among the millennial revolutionaries, Winstanley was by far the most radical in his vision of religious freedom, his determination to eradicate organized churches, and his assertion that a new law would protect and proliferate the reforms he advocated. He believed that believers from all religions will be united in the millennial rule of Christ, and he maintained that it was essential to transform England into an ideal Commonwealth before the final judgment, so that their nation could be rewarded for its reform by God. He believed in universal salvation - in order to prepare for the apocalyptic salvation of all, he wanted to establish God's universal acceptance of all religions as a law that protected freedom of religion.

Another shared issue is the authors' similar conception of almost universal suffrage. Eliot expanded his proto-democratic program based on near-universal manhood suffrage. His definition of the electoral subjects was, for all practical purposes, the same as that of Winstanley: "All economical self-sufficient males are entitled to vote. Women, children and Servants, or Sons living with their parents, as in the condition of Servants" were all "virtually comprehended in their father's covenant" (Eliot, 145-46) . For Winstanley, the broad sphere of people who were "fit to choose officers in a commonwealth" included "all civil livers, as drunkards, quarrellers, fearful ignorant men....all these are empty substance, and cannot be experienced men, therefore not fit to be chosen officers in a commonwealth; yet they may have a voice in the choosing" (Winstanley, III, 326) . In other words, in Winstanley's community all manhood were fit to vote except those who were 
interested in (or had supported) the monarchical power. Those were the only to be proscribed to choose or to be chosen officers.

Other important parallel in these two utopias is the emergence of a culture of fear as an endogenous reason of the prevailing uncertainty of the revolutionary period. The fear of a revival monarchy, or any other rule that not the Christ's, became a powerful drive in the search for social balance and stability. Holstun states:

In The Christian Commonwealth Eliot turns his Praying-Town experiment with the congregational disciplining of sachems into a model utopia promising revolution-torn England a complete democratic transformation that will protect it against the return of any sachemic rule except that of King Jesus. (144-45)

Just like in Eliot, the fear of a revival monarchy, was imminent along Winstanley's text and it even borders on the obsession. Winstanley suspected royalist conspiracies and kingly supporters everywhere. Thus everyone who didn't share his political views was suspected of supporting tyranny and considered to be an agent of the old monarchical order. Indeed, the fear of tyranny is directly reflected in his code of laws where he states:

He or she who calls the earth his and not his brother's shall be set upon a stool, with those words written in his forehead, before all the congregation; and afterwards be made a servant for twelve month under the taskmaster. If he quarrel, or seek by secret persuasion, or open rising arms, to set up such a kingly property, he should be put to death. (Winstanley, 383)

Moreover there was a more ideologically fear than the royalist return of the monarchy. It was definitely the fear of Cromwell's power and the lost of democratic ideals. Eliot feared of the threatened secular predominance of Cromwell and the Rump Parliament. He viewed them, so far as the king, as usurper of Christ's political power on earth (Holstun, 149). Winstanley, also feared Cromwell's misuse of power. He realized that his power represented a considerable threat to the ideas of his cause and he warned him of misusing it:

The righteous power of the creation is the same still. If you and those in power with you should be found walking in the king's steps, can you secure yourselves or posterities from an overturn? 
Surely not... For if he [God] would not spare kings who have sat so long at his right hand governing the world, neither will he regard you, unless your ways are found more righteous than King's (Winstanley, 276).

With the conviction that his utopian vision represented divine providence, he assumed the role of a prophet, warning Cromwell of the consequence of abusing his power and not living up to the ideals of the Revolution. However, at the same time, he needed Cromwell, as he stated: "You are in place and power to see all burdens taken off from your friends, the commoners of England" (Winstanley, 278). He identified Cromwell as the political figure to realize his political ambitions. Cromwell represented Winstanley's last hope for utopian fulfillment. According to this, Cromwell could become either the architect of a new republic or the tyrant enslaving his state. Thus, in spite of the fear towards the misuse and abuse of Cromwell's power, both Eliot and Winstanley knew Cromwell's importance as a central force of the Interregnum politics.

In The Christian Commonwealth as in The Law of Freedom there were no vagrant populations. Even in the democratic political system as Eliot's, free persons in free spaces raise the specter of wandering chaos. Both authors feared the chaos as a threat to their well ordered utopias. So the law and work became a relevant key for the stability of their utopias. Regarding the "Work" issue, both authors shared the puritan context of this concept. Eliot as a puritan missionary emphasized the work in the context of the puritan asceticism as a means to glorify God. "And they are to declare the Council and Will of God, touching war and Peace, and accordingly transmit the work to such of the Rulers as they judge most meet to accomplish the same. Also to take for, and provide means for public welfare and subsistence, by trading, ..fishing... with all other necessary and useful occupations" ( Eliot, 182-4).

Winstanley also by stressing the puritan ideal of hard work, understood work to be a blueprint to achieve political and social salvation to map the future of English society. In The Law of Freedom the idle and vagrants were severely punished. Labor was compulsory but not paid. Everybody should have a work. In his utopia the work comes up with such integrity that the various modalities of the Governments were divided into 
categories called "Works" such as: "The Work of a Father or Master of a Family"; "The Work of a Peace-maker", "The Work of Overseers or Postmaster". Even the task of education was also seen as a noble work. For Winstanley freedom would never mean freedom of work, as it was in the Milton's Eden. For Winstanley Freedom was consistently defined as freedom to work, to farm the land. "The freedom lies where a man receives his nourishment and preservation, and that is in the use of the earth"( I, 299). And "work" was so fundamental in his utopian vision that even the Cromwell's task was thus defined since what he would have ahead was "the work of reformation". Moreover Winstanley asked his readers: "Be as industrious bee, suck out the honey and cast away the weeds". Through this powerful metaphor, he invites the reader himself to undertake a mental work, while reading his utopia, a sort of an intellectual endeavor that will help the reader to find the accurate interpretation of Winstanley's utopian rhetoric.

We have displayed some of the most relevant parallels between these two authors, which we can be summarized as follows:

- Both wrote their utopias in 1652; ( despite the fact that Eliot's was only published in 1659)

- Both offered Cromwell their utopian models as templates to be emulated by the English nation having each of them the authority of the scripture and of their empirical bases: The Indian Praying Towns of Natick and the Diggers communities at St. George's Hill;

- The aspirations and impulses that impelled them to act, allowed them to direct their utopias to an expectant reality and reshape the boundaries of the literary genre. Utopia became dynamic and action-oriented.

- They relied on a biblical code of laws, on a controlled system by mutual surveillance and on the power of the labor/work as primary factors to ensure the achievement of their utopias;

- They displayed the very same fears: the royalist return of the monarchy and at the same time the fear of Cromwell's predominance and misuse of power. 
- In both utopias the authors banned the lawyers as they both saw the profession as the primary enemies of their cause;

- They both displayed in their utopias an high level of radicalism concerning their intentions to reshape the future of the English commonwealth.

Since the differences are countless I wouldn't find room to lengthen them within the boundaries of this paper. Nevertheless I should merely focus on their different textual methods, with Eliot attempting to exclude all merely human prudence trying to eradicate all man-made institutions and Winstanley attempting to incorporate it - as he developed a remarkable theory of selfhood and believed that God was in men's inner life.

While Eliot conceived a political perfection only achievable by a divine act, Winstanley tried to maintain a strictly idiosyncratic methodology supporting an individualistic epistemology: it was individuals, in interaction with inner self, who bore the worldly power. He reconceptualized how humans should conceive of their capacity for choice and change, assert their freedom, and realize their potential as creators. By stressing the possibility of a paradisiacal reorganisation of the social and economic world, he was definite in his assertion that this was to be achieved through the action of the spirit.

In conclusion these examples are only two among many that depict the dynamic of these utopias which released utopism from its traditionally passive position within the realm of contemplative literature and transposed it into the active realm of Interregnum politics. Nevertheless both of the writers were ignored and silenced by their contemporary critics. In fact we can consider they were far in advance their epoch. If we can understand Eliot's utopia as a proto-democratic project "a hybridism of theocracy and democracy" ( Holstun 145), of a strict biblical literalism and a radically popular political program based on near-universal manhood suffrage, at the same time, we understand Winstanley's utopia as a proto- comunism since the combination of his unorthodox political beliefs and his radical political agenda have marked him as a progressive thinker whose ideas presaged those of later 
communist revolutionaries. As Lewis H. Berens puts it: "He was, in truth, one of the most courageous, far-seeing and philosophic preachers of social righteousness that England has given to the world" (171). Scholarly interest in Winstanley in general is relatively recent. In 1984 G. E. Aylmer observes the Winstanley had been largely forgotten for two centuries, and that even after his work attracted the attention of late nineteenth century historians, he remained obscure until the 1960s. Not until the resurrection by Bernstein (1985) was attention first directed to the fact that the most advanced thinker of the English Revolution had been completely neglected by its historians.

By his turn, Eliot's visions articulated in The Christain Commonwealth, put him far outside the mainstream on either side of the ocean. He was a proto-democratic whose ideas, so much as Winstanley's, put him actually ahead his own time and his contemporaries. According to Holstun, his work with the remnants of the Algonquian civilization, was the single most ambitious utopian project within the larger Puritan utopia of New England (103). Nevertheless neither Eliot nor Winstanley have received much attention from historians of utopian thought. For the most part they have been left to historians of religion, millennialism, political theory, hagiography or historian of Indian-white relations (in Eliot's case).

In spite of their effort they haven't had a major place among others of their time, and the historians of utopian thought have not paid them the deserved attention, maybe, as Holstun states, because their works were not so much about literature as they were about people. However, both worked intensively to connect utopia to reality. They were, according Holstun: "the most important utopian theorist and practitioner in his respective realm, in the seventeenth century". 


\section{References}

Berens, Lewis, H. 2007. The Digger Movement in the days of the Commonwealth, Wales: Merlin Press.

Campanella, Tommaso. 1981. The City of the Sun, in famous Utopias of the Renaissance, Ed. Frederic R. White. Putney: Hendricks House.

Cogley, Richard. 1999. John Eliot's Mission to the Indians before King Philip's war, Massachusetts: Harvard University Press, available at: http://digitalcommons.unl.edu/libraryscience/19/

Davis, J.C. 1981. Utopia and Ideal society: A Study of English Utopian Writing 1516-1700, Cambridge: Cambridge University Press.

Eliav-Feldon, Mriram. 1982. Realistic Utopias: The Ideal Imaginary Societies of the Renaissance, 1516-1630, Oxford: Clarendon.

Eliot, John, 1846. The Christian Commonwealth: Or, the Civil of the Rising Kingdom of Jesus Christ, Collections of the Massachusetts Historical Society, $3^{\text {rd }}$ ser. 9; 1659

Holstun, James. 1987. A Rational Millennium, Puritan Utopias of Seventeenth- Century England and America, Oxford: Oxford University Press.

Levitas, Ruth. 1989. The Concept of Utopia, Syracuse: Syracuse UP1990More, Sir Thomas, Utopia, Ed. George M. Logan and Robert M. Adams. Cambridge: Cambridge University Press.

Smith, Nigel. 1989. Perfection Proclaimed: Language and Literature in English Radical Religion 1640-1660, Oxford: Clarendon Press.

Thomas, Keith. 1987. "The utopian Impulse in Seventeenth-Century England" in Between Dream and Nature: Essays on Utopia and Dystopia, Amsterdam: Dominic Baker-Smith and C.C. Bartfoot.

Yack, Bernard. 1992. The Longing for Total Revolution, Berkely: University of California Press.

Winstanley, Gerrard. The Law of Freedom and Other Writings, Ed. Christopher Hill Cambridge: Cambridge University Press, 1883, available at: http://www.bilderberg.org/land/lawofree.htm Lexicon. January 2012. Web. 